\title{
Islam dan Relasi Agama-Agama dalam Perspektif Hadis dan Implementasinya di Lembaga Pendidikan
}

\author{
(Islam and the Relation of Religions in the Perspective of Hadith and Its \\ Implementation in Educational Institutions)
}

\author{
Sismanto \\ Pascasarjana Universitas Islam Malang, Indonesia \\ sirilwafa@gmail.com
}

DOI: $10.29240 /$ alquds.v5i2.2518

Submitted: 2021-02-16 | Revised: 2021-08-09 | Accepted: 2021-08-20

\begin{abstract}
As a pluralistic country consisting of various diverse backgrounds, Indonesia can potentially lead to horizontal conflicts if not managed properly. This article discusses the relationship between Islam and religions, which has become an issue throughout humanity's history. Descriptive research uses the takhrij hadith method and traces information sourced from books and journals that find the topics studied. In editorial terms, some traditions show an accommodative relationship between Islam and other religions, but some seem discriminatory. Thus, there are fluctuations and dynamics of relations between Islam and other religions, with nuances of harmony and disharmony. Therefore, there needs to be a reading of the hadiths constructively implemented in education as a conducive place for teaching Islam multicultural values.
\end{abstract}

Keywords: hadith; religious relations; religious practices; educational institutions

Abstrak. Indonesia sebagai negara yang majemuk yang terdiri dari berbagai latar kamejemukan bila tidak dikelola dengan baik dapat berpotensi konflik horizontal. Artikel ini mendiskusikan relasi Islam dan agama-agama yang menjadi isu aktual sepanjang sejarah kemanusiaan. Penelitian menggunakan deskriptif kualitatif dengan metode takhrij hadis dan menelusuri informasi yang bersumber dari buku-buku dan jurnal-jurnal yang ada kaitannya dengan topik yang diteliti. Secara redaksional, ada hadis yang menampakkan relasi yang akomodatif antara Islam dengan agama lain, namun ada juga yang terkesan diskriminatif. Dengan demikian, ada fluktuasi dan dinamika relasi Islam dan agama-agama lain, baik yang bernuansa harmoni maupun disharmoni. Karena itu, perlu ada pembacaan terhadap hadis-hadis secara konstruktif agar dapat diimplementasikan di dunia pendidikan sebagai wahana yang kondusif untuk membelajarkan nilai-nilai multikultural.

Kata Kunci: hadis; relasi agama-agama; praktik keagamaan; lembaga pendidikan 


\section{Pendahuluan}

Islam adalah agama langit dengan membawa ajaran-ajaran langit untuk dapat membumikan ajaran agamanya, maka Allah mengirim utusan. Islam hadir di dunia dibawakan oleh Nabi Muhammad SAW yang mengajarkan kepada manusia tentang keindahan dan keberagaman dan Islam hadir sebagai agama penyempurna yang mengajarkan tentang kemajemukan dan pluralitas. Islam mengajarkan bagaimana mengatur perilaku umatnya untuk berkomunikasi langsung umat beragama, baik dengan sesama muslim maupun interaksi antar umat Islam dengan umat yang lainnya.

Ajaran tentang pluralitas, multikultural, dan kemajemukan sebagaimana yang diungkapkan Heru Suparman dalam temuan penelitiannya memberikan pandangan Al-Qur'an tentang kemajemukan bahwa ajaran Islam tidak ada yang kontradiktif terutama kaitannya Alquran sebagai dasar hukum Islam. Sebagaimana ditegaskan Alquran bahwa keberagaman yang ada tersebut dapat dijadikan pelajaran bagi orang yang beriman untuk mempelajari dan menjadikannya sebagai pedoman ${ }^{1}$. Sementara kehadiran hadis merupakan sabda Nabi SAW sekaligus dijadikan sebagai sumber hukum kedua setelah Al Quran ${ }^{2}$. Dalam memahami urusan agama Amir Mu'allim, memberikan dua persepsi, pertama agama dijadikan sebagai doktrin, dan kedua agama sebagai produk pemahaman manusia atas doktrin agama. Dalam hubungan ini, agama sebagai doktrin memiliki prinsip, misalnya keadilan, persamaan, pluralitas, kebebasan, demokrasi, dan kemanusiaan. Prinsip-prinsip ini stabil dan tidak berubah. Namun, prinsip tersebut harus diimplementasikan dengan bijaksana dalam kehidupan manusia. Oleh karena itu, radikalisme (terorisme, jihad, dan lain-lain) yang berkaitan dan mengatasnamakan agama harus dipahami secara menyeluruh karena termasuk bagian dari agama sebagai ideologi ${ }^{3}$.

Indonesia sebagai negara yang majemuk yang terdiri dari berbagai latar kamejemukan bila tidak dikelola dengan baik dapat berpotensi konflik horizontal. ${ }^{4}$ Beberapa kasus dan konflik bernuansa SARA, baik itu dari agama maupun suku perlu dicarikan solusi yang tepat dengan penguatan moderasi beragama. Umi Sumbullah dalam penelitiannya mengungkapkan bagaimana pandangan tokoh

\footnotetext{
${ }^{1}$ Heru Suparman, "Multikultural Dalam Perspektif Alquran," AL QUDS : Jurnal Studi Alquran Dan Hadis 1, no. 2 (December 1, 2017): 2580-3190, https://doi.org/10.29240/alquds.v1i2.250.

2 Istianah, "Kritik Terhadap Penisbatan Riwayat Hadis: Studi Atas Hadis-Hadis Palsu," Riwayah: Jurnal Studi Hadis 4, no. 1 (2018): 77-100, https://doi.org/http://dx.doi.org/10.21043/riwayah.v4i1.3319.

3 Amir Mu'allim, "Relasi Agama Dan Kekerasan," Unisia 29, no. 61 (September 21, 2006): 257-65, https://doi.org/10.20885/unisia.vol29.iss61.art2.

${ }^{4}$ Sismanto and Riswadi, "Forms of Cooperation Between Religions; A Tafsir Perspektif," Syamil: Journal of Islamic Education 9, no. 1 (2021): 21-38, https://doi.org/10.21093/sy.v9i1.3201.
} 
agama tentang kemajemukan dan kerukunan umat beragama. dengan mengambil latar penelitian di Kota Malang, penelitiannya memfokuskan pada pemberian makna kerukunan umat beragama dan pluralisme. Hasil penelitiannya mengungkapkan bahwa upaya untuk mendukung terciptanya kerukunan umat beragama adalah adanya sikap positif, kesadaran, dan kemauan untuk saling memahami dan berbagi peran. Elit agama di kota Malang mengakui bahwa halhal yang dapat mengganggu terjadinya kerukunan antar umat beragama adalah ego klaim kebenaran fanatisme dan eksklusivisme ${ }^{5}$. Ada kesan mendiskreditkan Islam berasal dari beberapa hadits bahwa Islam mengajarkan perilaku dan pergaulan sebagai seorang muslim dengan umat beragama lain, Islam juga mengajarkan etika pergaulan kepada orang yang berlainan jenis dari sisi kelamin, budaya, sosial, maupun suku. Hadirnya hadis-hadis yang diskriminatif ini pada gilirannya akan mempengaruhi perilaku dan sikap umat muslim dengan umat beragama lainnya dalam tatanan dan kehidupan sehari-hari.

Salamah Noorhidayati mengungkapkan bahwa ada beberapa hadis yang dianggap memiliki nilai diskriminatif bagi umat agama lain misalnya; adalah hadis tentang larangan menikahi, meniru, dan menyerupainya, perintah berperang, membunuh Yahudi dan Nasrani serta larangan memulai memberi salam, dan hadis-hadis lain yang dipandang diskriminatif. Kaitannya dengan mengucapkan salam dalam konteks kehidupan pluralitas dan kemajemukan beragama, tentu hal ini akan menjadi permasalahan tersendiri. Di satu sisi larangan tidak diperbolehkan memulai mengucapkan salam kepada mereka, sementara di sisi lain dalam konteks kemanusiaan tentu saja menjawab salam adalah sebuah keniscayaan. Bagi sebagian umat muslim, hadis-hadis tersebut di atas dipahami sebagai norma sekaligus ideologi tentang bagaimana bergaul dengan umat beragama lainnya. Bila hadits-hadits tersebut di atas hanya dimaknai secara tekstual saja, tentu akan memberikan pandangan radikal dalam beragam sehingga perlu tidak hanya membaca hadis secara tekstual tetapi juga dilihat secara kontekstual bagaimana hadis itu disampaikan oleh Nabi Muhammad konteks sosio-kultural yang melatarinya ${ }^{6}$.

Di era sekarang ini tuntutan akan kesetaraan harkat dan martabat manusia dihadapan hukum maupun penegakan hak-hak asasi manusia semakin muncul di permukaan. Adanya sikap sikap yang intoleran dan diskriminatif terhadap manusia menjadi persoalan yang perlu diselesaikan. Sekolah sebagai sistem sosial merupakan tempat yang optimal dan kondusif serat dapat dijadikan tempat

${ }^{5}$ Umi Sumbulah and Wilda Al Aluf, Fluktuasi Relasi Islam-Kristen Di Indonesia Pendekatan Sosio-Historis (Malang: UIN Maliki Press, 2015).

'Salamah Noorhidayati, "Hubungan Antar Umat Beragama Dalam Perpektif Hadits," KALAM 10, no. 2 (December 30, 2016): 491-516. 
sebagai penguatan moderasi beragama dalam masyarakat majemuk dan beragam. Noor Sulistyobudi, dkk menyebut angka kekerasan pelajar di Daerah Istimewa Yogyakarta (DIY) berdasar catatan Polresta Yogyakarta, pada tahun 2011 tercatat 9 kasus, tahun 2012 dan 2013 terdapat 5 kasus. Kasus kekerasan antar pelajar ini perlu dicermati Agar kasus serupa tidak muncul kembali dan kasus tersebut bukanlah berasal dari permasalahan Sara (kekerasan antar adat, budaya, suku, dan agama) Karena pada dasarnya belajar merupakan usia yang sedang dalam proses pencarian entitas dan identitas ${ }^{7}$.

Sejumlah penelitian membahas bidang-bidang tertentu dalam perspektif Islam, Al Qur'an maupun hadis, seperti; entrepreneurship dalam perspektif Islam ${ }^{8}$, enterpreneurship perspektif hadis ${ }^{9}$, pengelolaan air dalam perpesktif Islam $^{10}$, poligami dalam perspektif hadis ${ }^{11}$, Agama dan kesejahteraan hewan ${ }^{12}$, pendidikan dalam perspektif hadis ${ }^{13}$, pendidikan anti kekerasan dalam perspektif

${ }^{7}$ Noor Sulistyobudi, Bambang Suta, and Salamun, Implementasi Pendidikan Multikultural Di SMA Daerah Istimewa Yogyakarta (Yogyakarta: Balai Pelestarian Nilai Budaya (BPNB) Yogyakarta, 2014), 2.

${ }^{8}$ P R M Faizal, A A M Ridhwan, and A W Kalsom, "The Entrepreneurs Characteristic from Al-Quran and Al-Hadis," International Journal of Trade, Economics and Finance 4, no. 4 (2013): 191-96; Ali Aslan Gümüsay, "Entrepreneurship from an Islamic Perspective," Springer Science+Business Media Dordrecht, no. September 2013 (2015): 199-208, https://doi.org/10.1007/s10551-014-2223-7; Rasem N. Kayed and M. Kabir Hassan, "Islamic Entrepreneurship: A Case Study of Saudi Arabia," Journal of Developmental Entrepreneurship 15, no. 4 (2010): 379-413, https://doi.org/10.1142/S1084946710001634; Nazamul Hoque, Abdullahil Mamun, and Abdullah Mohammad Ahshanul Mamun, "Dynamics and Traits of Entrepreneurship: An Islamic Approach," World Journal of Entrepreneurship, Management and Sustainable Development 10, no. 2 (2014): 128-42, https://doi.org/10.1108/wjemsd-04-2013-0027.

9 Zulfahmi Alwi et al., "Hadith Corresponding Thoughts on the Ethical Interacting Behavior of Young Entrepreneurs in Indonesia," Journal of Asian Finance, Economics and Business 8, no. 3 (2021): 331-39, https://doi.org/10.13106/jafeb.2021.vol8.no3.0331.

${ }^{10}$ M Saifuddin Ihya, "Water Management in Hadith Perspective," Journal of Hadith Studies 1, no. 2 (October 25, 2018): 54-69, https://doi.org/10.32506/johs.v2i2.364.

${ }^{11} \mathrm{Rahmin} \mathrm{T}$. Husain et al., "Polygamy in the Perspective of Hadith: Justice and Equality among Wives in A Polygamy Practice," MADANLA: JURNAL KAJLAN KEISLAMAN 23, no. 1 (July 7, 2019): 93, https://doi.org/10.29300/madania.v23i1.1954.

${ }^{12}$ Sira Rahman, "Religion and Animal Welfare-An Islamic Perspective," Animals 7, no. 12 (February 17, 2017): 11, https://doi.org/10.3390/ani7020011.

${ }^{13} \mathrm{M}$. Chalis and Syahril Syahril, "Education in the Perspective of Hadits (Analysis of Education in the Dimensions of the Hadith)," in Proceedings of the 1st International Conference on Social Science, Humanities, Education and Society Development, ICONS 2020, 30 November, Tegal, Indonesia (EAI, 2021), https://doi.org/10.4108/eai.30-11-2020.2303686. 
hadis ${ }^{14}$, pembiayaan pendidikan perspektif hadis ${ }^{15}$, kesehatan publik ${ }^{16}$, puasa dan sistem kekebalan tubuh ${ }^{17}$, psikologis kegiatan $\mathrm{amal}^{18}$, dan belum ada penelitian yang membahas relasai antar agama dalam perspektif hadis serta implementasinya pada lembaga pendidikan.

Pada akhirnya, naskah ini difokuskan pada kajian hadis tentang Islam dan relasi agama-agama yang mendasarkan pada tiga pertanyaan utama: (1) bagaimana redaksi hadis tentang Islam dan relasi agama-agama, (2) kajian takhrij al-hadits untuk meneliti kualitas sanad dan matan hadis, dan (3) bagaimana konteks sosiohistoris yang melatari kemunculannya. Hal ini berkaitan dengan bagaimana metode dan Interpretasi para ulama hadis dalam kitab-kitab syarah hadis beserta kaitan hadis-hadis Islam dan relasi Agama-agama dengan sejarah masa Nabi dan masa kekhilafahan Islam, dan bagaimana melakukan pembacaan ulang dalam konteks kekinian dan relevansinya dalam dunia pendidikan. Tujuan naskah penelitian ini memberikan gambaran yang utuh hadis tentang Islam dan relasi agama-agama beserta latar kehadirannya dan melakukan interpretasi ulang terhadap teks hadis sehingga pada gilirannya mendapatkan substansi dari ajaran Nabi dan mendudukkan hadis pada tempat semestinya.

\section{Inventarisasi Hadis-hadis tentang Islam dan Relasi Agama- Agama}

Berdasarkan penelusuran penelusuran hadis dengan menggunakan kata kunci "Yahudi dan Nasrani" pada ensiklopedi kitab 9 hadis, ditemukan beberapa hadis yang berkaitan erat antara hubungan Islam dan relasi agama-agama. Pada penelusuran tersebut ditemukan di dalam: (1) kitab hadis Bukhari ditemukan 3 hadis, (2) empat hadis pada kitab hadis Muslim, (3) satu hadis pada kitab hadis Abu Daud, (4) kitab Tirmidzi ditemukan 3 hadis, (5) lima hadis pada kitab hadis

${ }^{14}$ Imroatun Imroatun and Difla Nadjih, "Anti-Violence Education in the Perspective of Hadith,” Indonesian Journal of Islamic Early Childhood Education 1, no. 1 (2016): 121-30.

${ }^{15}$ Maslani Maslani et al., "The Hadith Perspective on Educational Funding," in Proceedings of the International Conference on Islamic Education (ICIE 2018), vol. 261 (Paris, France: Atlantis Press, 2018), 288-92, https://doi.org/10.2991/icie-18.2018.52.

${ }^{16} \mathrm{Ikmal}$ Ahmad Fauzi1 and Ecep Ismail, "The Concept of Public Health from Hadith Perspective," Gunung Djati Conference Series, Volume 4 (2021) Proceedings The 1st Conference on Usbuluddin Studies 4 (2021): 78-85.

${ }^{17}$ A Mostafazadeh and HR Khorasani, "Holy Quran and Hadith Perspective on Fasting and Immune System," Islam And Health Journal, 2014, 61-68, http:/ /www.iahj.ir/browse.php?a_id=69\&slc_lang=en\&sid=1\&printcase=1\&hbnr=1\&hmb=1.

${ }^{18}$ Tahere Mohseni and Khadijeh Ahmadi Bighash, "Psychological Effects of Charitable Activities on the Worldly Mental Health and Eternal Happiness of the Hereafter from the Perspective of the Qur'an and Hadith," International Journal of Multicultural and Multireligious Understanding 7, no. 6 (2020): 180, https://doi.org/10.18415/ijmmu.v7i6.1625. 
Nasai, (6) Satu hadis pada kitab Ibnu Majah, (7) 42 hadis pada kitab hadis Ahmad, (8) satu hadis pada kitab hadis Malik, (9) dua hadis pada kitab hadis Darimi.

\section{Kitab Hadis Bukhari}

Berdasarkan penelusuran kitab Bukhari dengan kata kunci 'Yahudi dan Nasrani" mendapatkan sejumlah 3 hadis. Hadis-hadis tersebut ditemukan pada hadis nomor 4604 yang berkaitan dengan pengumpulan Al-Qur'an, pada pada hadis nomor 5368 yang berkaitan dengan kain dan khamisah, dan pada pada hadis nomor 6775 berkaitan dengan sabda Nabi Muhammad SAW, "Sungguh, kalian akan mengikuti jejak orang-orang sebelum kalian". Untuk mempermudah pemahaman tentang hadis-hadis yang dimaksud berikut ini dituliskan dalam bentuk tabel.

Tabel 1 Hadis Islam dan Relasi Agama-agama dalam Kitab Hadis Bukhari

\begin{tabular}{|c|c|c|c|}
\hline No & $\begin{array}{l}\text { Nomor } \\
\text { Hadis }\end{array}$ & Bab Bahasa Indonesia & Bab Bahasa Arab \\
\hline 1 & 4604 & Pengumpulan Al quran & جمع القرآن \\
\hline 2 & 5368 & Kain dan Khamisah & الأكسية والخمائص \\
\hline 3 & 6775 & $\begin{array}{l}\text { Sabda Nabi SAW, } \\
\text { "Sungguh, kalian akan } \\
\text { mengikuti jejak orang- } \\
\text { orang sebelum kalian" }\end{array}$ & سنن من كان النبي صلى الله عليه وسلم لتتبعن \\
\hline
\end{tabular}

\section{Kitab Hadis Muslim}

Berdasarkan penelusuran kitab Muslim dengan kata kunci "Yahudi dan Nasrani" ditemukan 4 hadis. Hadis-hadis tersebut ditemukan pada hadis nomor 3926 tentang menyelisihi Yahudi dengan menyemir rambut في غخالفة اليهود في الصبغ hadis nomor 4030 tentang larangan memulai ahli kitab dalam memberikan salam, hadis nomor 4822 tentang mengikuti kebiasaan Yahudi dan Nashara, hadis nomor 4971 tentang "diterimanya taubat orang yang membunuh banyak manusia". Untuk mempermudah pemahaman tentang hadis-hadis yang dimaksud berikut ini dituliskan dalam bentuk tabel. 
Tabel 2 Hadis Islam dan Relasi Agama-agama dalam Kitab Hadis Muslim

\begin{tabular}{|c|c|c|c|}
\hline No & $\begin{array}{c}\text { Nomor } \\
\text { Hadis }\end{array}$ & Bab Bahasa Indonesia & Bab Bahasa Arab \\
\hline 1 & 3926 & $\begin{array}{l}\text { Menyelisihi Yahudi dengan } \\
\text { menyemir rambut }\end{array}$ & في مخالفة اليهود في الصبغ \\
\hline 2 & 4030 & $\begin{array}{l}\text { Larangan memula kepada } \\
\text { ahli kitab dalam } \\
\text { memberikan salam }\end{array}$ & 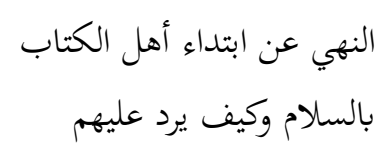 \\
\hline 3 & 4822 & $\begin{array}{l}\text { Larangan mengikuti } \\
\text { kebiasaan Yahudi dan } \\
\text { Nasrani }\end{array}$ & اتباع سنن اليهود والنصارى \\
\hline 4 & 4971 & $\begin{array}{l}\text { Diterimanya taubat orang } \\
\text { yang membunuh } \\
\text { meskipun yang dibunuh } \\
\text { banyak }\end{array}$ & قبول توبة القاتل وإن كثر قتله \\
\hline
\end{tabular}

\section{Kitab Hadis Abu Daud}

Berdasarkan penelusuran kitab Muslim dengan kata kunci "Yahudi dan Nasrani" hanya ditemukan 1 hadis pada nomor 378 tentang membangun masjid, yang berbunyi:

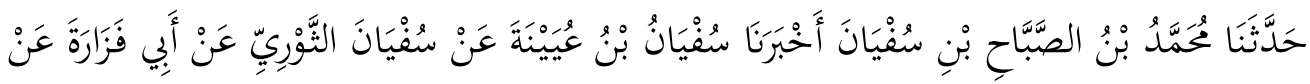

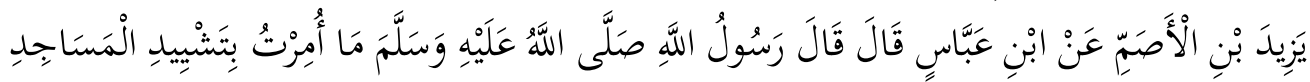

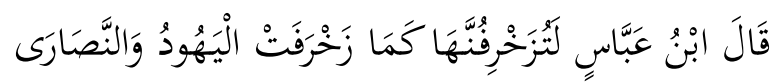

Telah menceritakan kepada kami Mubamad bin Ash Shabbah bin Sufyan telah mengabarkan kepada kami Sufyan bin 'Uyainah dari Sufyan Ats Tsauri dari Abu Fazarah dari Yazid bin Al Ashamm dari Ibnu Abbas dia berkata; Rasulullah Shallallahu alaibi wasallam bersabda: "Saya tidaklah diperintabkan untuk mengbiasi masjid-masjid." Ibnu Abas berkata; "Sungguh kalian akan menghiasi Masjid-masjid sebagaimana orang-orang Yahudi dan nasrani menghiasi (tempat ibadah mereka)." 


\section{Hadis Kitab Tirmidzi}

Berdasarkan penelusuran hadis Kitab Turmidzi dengan kata kunci "Yahudi dan Nasrani" ditemukan 3 hadis. Hadis-hadis tersebut ditemukan pada hadis nomor 2624 tentang mengucapkan salam untuk ahli dzimmah, nomor hadis 2797 tentang permisalan anak Adam, ajalnya dan angan-angannya, dan hadis nomor 3029 tentang diantara surat at taubah. Untuk mempermudah pemahaman tentang hadis-hadis yang dimaksud berikut ini dituliskan dalam bentuk tabel.

Tabel 3 Hadis Islam dan Relasi Agama-agama dalam Kitab Hadis Tirmidzi

\begin{tabular}{|c|c|c|c|}
\hline $\mathrm{No}$ & $\begin{array}{l}\text { Nomor } \\
\text { Hadis }\end{array}$ & Bab Bahasa Indonesia & Bab Bahasa Arab \\
\hline 1 & 2624 & $\begin{array}{l}\text { Mengucapkan salam } \\
\text { untuk ahli dzimmah }\end{array}$ & ما جاء في التسليم على أهل الذمة \\
\hline 2 & 2797 & $\begin{array}{l}\text { Permisalan anak adam, } \\
\text { ajalnya dan angan- } \\
\text { angannya }\end{array}$ & ما وأمله جاء في مثل ابن آدم وأجله \\
\hline 3 & 3029 & Diantara surat attaubah & ومن سورة التوبة \\
\hline
\end{tabular}

\section{Hadis Kitab Nasai}

Berdasarkan penelusuran hadis kitab Nasai dengan kata kunci "Yahudi dan Nasrani" ditemukan 5 hadits. Hadis-hadis tersebut ditemukan pada hadis nomor 696 tentang larangan menjadikan kuburan sebagai masjid, hadis nomor 1351 tentang kewajiban menunaikan jumatan, hadis nomor 2020 tentang menjadikan kuburan sebagai masjid, hadis nomor 4724 tentang Berapa diyat orang kafir, hadis nomor 4985 tentang diijinkan memakai khidhab (pacar, semir). Untuk mempermudah pemahaman tentang hadis-hadis yang dimaksud berikut ini dituliskan dalam bentuk tabel.

Tabel 4 Hadis Islam dan Relasi Agama-agama dalam Hadis Kitab Nasai

\begin{tabular}{|c|c|l|c|}
\hline No & $\begin{array}{c}\text { Nomor } \\
\text { Hadis }\end{array}$ & \multicolumn{1}{|c|}{ Bab Bahasa Indonesia } \\
\hline 1 & 696 & $\begin{array}{l}\text { Larangan menjadikan } \\
\text { kuburan sebagai masjid }\end{array}$ \\
\hline 2 & 1351 & $\begin{array}{l}\text { Kewajiban menunaikan } \\
\text { jumatan }\end{array}$ & النهي عن ايجاب الجماذ الجبون \\
\hline
\end{tabular}




\begin{tabular}{|c|c|l|c|}
\hline 3 & 2020 & $\begin{array}{l}\text { Menjadikan kuburan sebagai } \\
\text { masjid }\end{array}$ & اتخاذ القبور مساجد| \\
\hline 4 & 4724 & Berapa diyat orang kafir & $\begin{array}{l}\text { (إذذن بالخضاب } \\
\text { (pacar, semir) }\end{array}$ \\
\hline 5 & 4985 & $\begin{array}{l}\text { Diijinkan memakai khidhab } \\
\text { (pacmir }\end{array}$ & \\
\hline
\end{tabular}

\section{Hadis Kitab Ibnu Majah}

Berdasarkan penelusuran kitab hadis Ibnu Majah dengan kata kunci "Yahudi dan Nasrani" hanya ditemukan 1 hadis pada nomor 378 tentang membangun masjid, yang berbunyi:

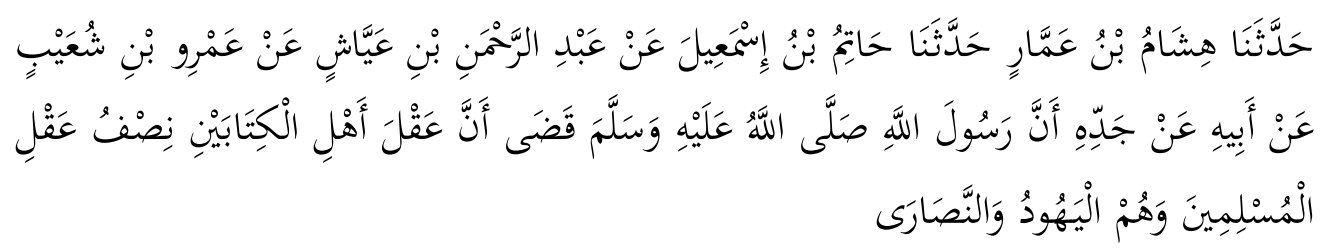

Telah menceritakan kepada kami Hisyam bin Ammar, telah menceritakan kepada kami Hatim bin Isma'il dari Abdurrabman bin Ayyasy dari Amru bin Syu'aib dari Ayahnya dari Kakeknya, ia berkata; "Sesunggubnya Rasulullah shallallabu 'alaibi wasallam menetapkan bukum bahwa diyat membunuh dua kalangan abli kitab adalah separuh dari diyat kaum Muslimin. Mereka adalah orang-orang Yabudi dan Nasrani”.

\section{Kitab Hadis Ahmad}

Berdasarkan penelusuran kitab hadis Ahmad dengan kata kunci "Yahudi dan Nasrani" ditemukan 42 hadis. Hadis-hadis tersebut ditemukan pada hadis nomor 6 tentang permulaan wahyu, hadis nomor 39 tentang shalat bagian dari iman, hadis nomor 43 tentang bertambah dan berkurangnya iman, hadis nomor 122 tentang Firman Allah Ta'ala: "Dan tidaklah kalian diberi ilmu kecuali sedikit", hadis nomor 384tentang menghadap kiblat bagaimanapun keadaannya, hadis nomor 417 dan hadis 418 tentang shalat di tempat ibadah orang Yahudi dan Nasrani, hadis nomor 525 tentang orang yang mendapatkan satu rakaat shalat Ashar sebelum masuk waktu Maghrib, hadis nomor 568 dan hadis 569 tentang permulaan (diperintahkannya) azan.

Selanjutnya penelusuran hadis yang berkenaan Islam dan relasi agamaagama pada kitab hadis Ahmad ditemukan pada hadis nomor 827 tentang kewajiban shalat Jum'at, hadis nomor 847 tentang kaum wanita dan anak-anak, apakah mandi bila tidak menghadiri sholat pada hari Jum'at?, hadis nomor 991 
tentang memohon perlindungan dari siksa kubur saat terjadi gerhana, hadis nomor 996 tentang shalat gerhana dilaksanakan di masjid, hadis nomor 1207 tentang Sabda Nabi Muhammad SAW tentang mayat akan disiksa dikarenakan tangisan keluarganya, hadis nomor 1228 dan hadis nomor 1229 tentang berdiri untuk menghormati jenazah orang Yahudi, hadis nomor 1243 tentang menshalati jenazah di lapangan atau di masjid, hadis nomor 1244 tentang larangan menjadikan kuburan sebagai masjid, hadis nomor 1268, 1270, 1271 tentang anak kecil yang mati apakah wajib disholat dalam Islam?

Selanjutnya penelusuran hadis yang berkenaan Islam dan relasi agamaagama pada kitab hadis Ahmad ditemukan pada hadis nomor 1283 tentang Siksa kubur, hadis nomor 1286 tentang memohon perlindungan dari adzab qubur, hadis nomor 1296 tentang membicarakan keberadaan mayit (anak-anak kaum musyrikin), hadis nomor 196, 210, dan 214 tentang awal musnad Umar bin Khatthab RA, hadis nomor 4279, 5636, dan 6080 tentang musnad Abdullah bin Umar bin Khatthab RA, hadis nomor 6429 dan 6795 tentang musnad Abdullah bin 'Amru bin 'Ash RA, hadis nomor 6975, 7227, 7230, 7251, 7299, 7497, 7737, 7767, 8206, 8318, 8842, 9434, 9443, 9473, 10067, 10297, dan 10298 tentang musnad Abu Hurairah RA. Untuk mempermudah pemahaman tentang hadishadis yang dimaksud berikut ini dituliskan dalam bentuk tabel.

Tabel 5 Hadis Islam dan Relasi Agama-agama dalam Kitab Hadis Ahmad

\begin{tabular}{|c|c|c|c|}
\hline No & $\begin{array}{l}\text { Nomor } \\
\text { Hadis }\end{array}$ & Bab Bahasa Indonesia & Bab Bahasa Arab \\
\hline 1 & 6 & Permulaan wahyu & بلدء الوحي \\
\hline 2 & 39 & Shalat bagian dari iman & الصلاة من الإيمان \\
\hline 3 & 43 & $\begin{array}{l}\text { Bertambah dan } \\
\text { berkurangnya iman }\end{array}$ & زيادة الإيمان ونقصانه \\
\hline 4 & 122 & Firman Allah tentang ilmu & قإلا قليل الله تعالى وما أوتيتم من العلم \\
\hline 5 & 384 & $\begin{array}{l}\text { Menghadap kiblat } \\
\text { bagaimanapun keadaannya }\end{array}$ & التوجه نحو القبلة حيث كان \\
\hline 6 & 417,418 & $\begin{array}{l}\text { Shalat di tempat ibadah orang } \\
\text { Yahudi dan Nashrani }\end{array}$ & الصلاة في البيعة \\
\hline
\end{tabular}


Sismanto: Islam dan Relasi Agama-Agama dalam Perspektif Hadis | 569

\begin{tabular}{|c|c|c|c|}
\hline 7 & 525 & $\begin{array}{l}\text { Mendapatkan satu rakaat } \\
\text { shalat Ashar sebelum masuk } \\
\text { waktu Maghrib }\end{array}$ & 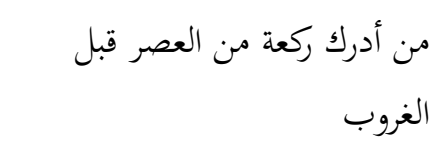 \\
\hline 8 & 568,569 & $\begin{array}{l}\text { Permulaan } \\
\text { (diperintahkannya) azan }\end{array}$ & بلدء الأذان \\
\hline 9 & 827 & Kewajiban Shalat Jum'at & فرض الجمعة \\
\hline 10 & 847 & $\begin{array}{l}\text { Kaum wanita dan anak-anak, } \\
\text { apakah mandi nila tidak } \\
\text { menghadiri sholat pada hari } \\
\text { Jum'at? }\end{array}$ & هل على النساء والصنيان لم يشهد الجمعة غسل \\
\hline 11 & 991 & $\begin{array}{l}\text { Memohon Perlindungan dari } \\
\text { Siksa Kubur Saat Terjadi } \\
\text { Gerhana }\end{array}$ & الكسوف من عذاب القبر في \\
\hline 12 & 996 & $\begin{array}{l}\text { shalat gerhana dilaksanakan } \\
\text { di Masjid }\end{array}$ & صلاة الكسوف في المسجد \\
\hline 13 & 1207 & $\begin{array}{l}\text { Sabda Nabi Muhammad } \\
\text { SAW tentang mayat akan } \\
\text { disiksa dikarenakan tangisan } \\
\text { keluarganya }\end{array}$ & يعذب المبي صلى الله عليه وسلم \\
\hline 14 & 1228,1229 & $\begin{array}{l}\text { berdiri untuk menghormati } \\
\text { jenazah orang Yahudi }\end{array}$ & من قام لجنازة يهودي \\
\hline 15 & 1243 & $\begin{array}{l}\text { Sholat jenazah di lapangan } \\
\text { atau di masjid }\end{array}$ & والمسلاة على الجنائز بالمصلى \\
\hline 16 & 1244 & $\begin{array}{l}\text { Larangan menjadikan } \\
\text { kuburan sebagai masjid }\end{array}$ & القبور يكره من اتخاذ المساجد على \\
\hline 17 & $\begin{array}{l}1268,1270 \\
1271\end{array}$ & $\begin{array}{l}\text { Anak kecil mati apakah wajib } \\
\text { dishalati dalam Islam? }\end{array}$ & عليه وهل يعرض أسب على فلى الصبي هل يصلى \\
\hline
\end{tabular}


570 | AL QUDS : Jurnal Studi Alquran dan Hadis vol. 5, no 2, 2021

\begin{tabular}{|c|c|c|c|}
\hline 18 & 1283 & Siksa kubur & ما جاء في عذاب القبر \\
\hline 19 & 1286 & $\begin{array}{l}\text { Memohon perlindungan dari } \\
\text { adab kubur }\end{array}$ & التعوذ من عذاب القبر \\
\hline 20 & 1296 & $\begin{array}{l}\text { Keberadaan mayit dari anak- } \\
\text { anak kaum musyrikin }\end{array}$ & ما قيل في أولاد المشركين \\
\hline 21 & $\begin{array}{l}196,210 \\
214\end{array}$ & $\begin{array}{l}\text { Awal musnad Umar bin Al } \\
\text { Khatthab RA }\end{array}$ & الهل عنه أوله عمر بن الخطاب رضي \\
\hline 22 & $\begin{array}{l}4279,5636 \\
6080\end{array}$ & $\begin{array}{l}\text { Musnad Abdullah bin Umar } \\
\text { bin Al Khatthab RA }\end{array}$ & مسند عبد الله بن عمر بن الخطاب \\
\hline 23 & 6429,6795 & $\begin{array}{l}\text { Musnad Abdullah bin 'Amru } \\
\text { bin Al 'Ash RA }\end{array}$ & مسند عبد الله بن عمرو بن العاص \\
\hline 24 & $\begin{array}{c}6975,7227, \\
7230,7251, \\
7299,7497, \\
7737,7767, \\
8206,8318, \\
8842,9434, \\
9443,9473, \\
10067, \\
10297, \\
10298,\end{array}$ & Musnad Abu Hurairah RA & مسند أبي هريرة رضي الله عنه \\
\hline
\end{tabular}

\section{Hadis Kitab Malik}

Berdasarkan penelusuran hadis Kitab Malik dengan kata kunci "Yahudi dan Nasrani" hanya ditemukan 1 hadis pada nomor 1387 tentang Yahudi diusir dari Madinah, yang berbunyi:

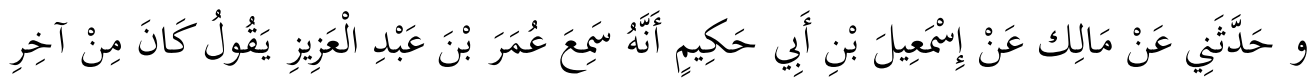

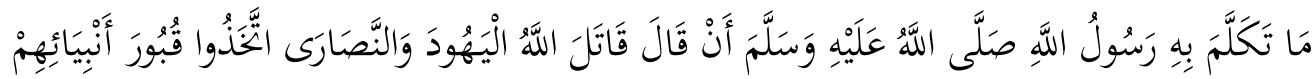

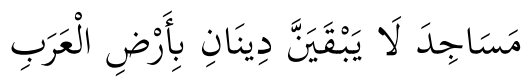


Telah menceritakan kepadaku Malik dari Isma'il bin Abu Hakim babwa ia pernah mendengar Umar bin Abdul Aziz berkata, "Salah satu sabda Rasulullah shallallabu 'alaibi wasallam yang terakhir adalah semoga Allah membinasakan orang Yabudi dan Nasrani. Mereka menjadikan kuburan para Nabi mereka sebagai masjid. Tidak akan ada dua agama di Tanah Arab".

\section{Hadis Kitab Darimi}

Berdasarkan penelusuran hadis Kitab Darimi dengan kata kunci "Yahudi dan Nasrani" ditemukan 2 hadis. Hadis-hadis tersebut ditemukan pada hadis nomor 290 tentang ilmu adalah takut dan taqwa kepada Allah dan hadis 1367 tentang Larangan menjadikan kuburan sebagai masjid. Untuk mempermudah pemahaman tentang hadis-hadis yang dimaksud berikut ini dituliskan dalam bentuk tabel.

Tabel 6 Hadis Islam dan Relasi Agama-agama dalam Kitab Hadis Darimi

\begin{tabular}{|c|c|c|c|}
\hline No & $\begin{array}{l}\text { Nomor } \\
\text { Hadis }\end{array}$ & Bab Bahasa Indonesia & Bab Bahasa Arab \\
\hline 1 & 290 & $\begin{array}{l}\text { Ilmu adalah takut dan } \\
\text { taqwa kepada Allah }\end{array}$ & بلاب من قال العلم الخشية وتقوى \\
\hline 2 & 1367 & $\begin{array}{l}\text { Larangan menjadikan } \\
\text { kuburan sebagai masjid }\end{array}$ & باب النهى عن اتخاذ القبور \\
\hline
\end{tabular}

\section{Kajian Takhrij Hadis Islam dan Relasi Agama-agama}

Secara terminologi takhrij hadis adalah menyampaikan suatu hadis dengan cara menyebut jumlah periwayatnya dan berdasarkan sumber yang disertai dengan metode periwayatannya ${ }^{19}$. Lebih lanjut Nasrullah memberikan penjelasan singkat tentang metode takhrij hadis menurutnya hadis bisa dilakukan dengan berbagai macam cara. Dalam tulisan tersebut, Nasrullah menyebutkan setidaknya ada 2 cara untuk melakukan kajian takhrij hadis dalam rangka meneliti kualitas sanad dan matan hadis. Pertama, takhrij hadis dilakukan melalui bantuan berbasis IT, melalui CD room, aplikasi berbasis web, dan atau melalui aplikasi yang sudah tersedia di Google play store. Kedua, melalui metode yang konvensional. Dalam

\footnotetext{
${ }^{19}$ Nasrullah, "Metodologi Kritik Hadis: (Studi Takhrij Al-Hadis Dan Kritik Sanad)," Jurnal Hunafa 4, no. 4 (2007): 403-16.
} 
menggunakan metode ini seorang pentakhrij hadis memerlukan bantuan buku sumber atau kamus sebagaimana karya A.J. Wensinck dalam "Miftah Kunuz alSunnah". Dalam penelitian ini pelaksanaan pengumpulan hadis-hadis Islam dan relasi agama-agama tersebut, penulis memanfaatkan bantuan ensiklopedia 9 kitab hadis. Penulis menggunakan takhrij hadits dengan bantuan aplikasi berbasis web http://www.infotbi.com dan dalam mentakhrij tema tersebut, penulis menggunakan secara bergantian dan acak dari keseluruhan metode takhrij yang ada.

Berdasarkan pengelompokan dan penelusuran hadits-hadits Islam dan relasi agama-agama, penulis menemukan dua kategori, yaitu hadis yang memberikan kesan dan sudut pandang akomodatif dan hadis yang memberikan kesan diskriminatif. Adapun beberapa teks hadis yang dipandang bersifat akomodatif, sebagai berikut:

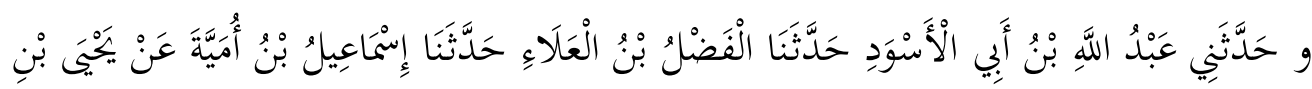

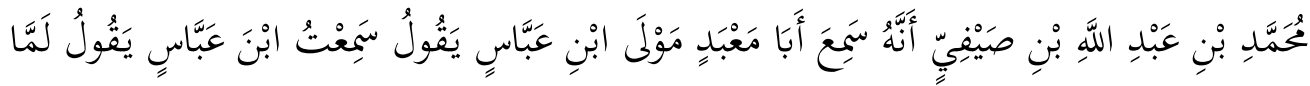

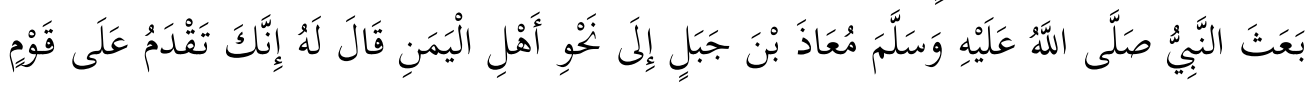

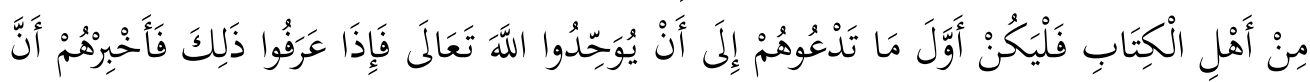

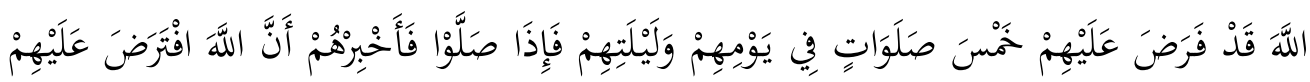

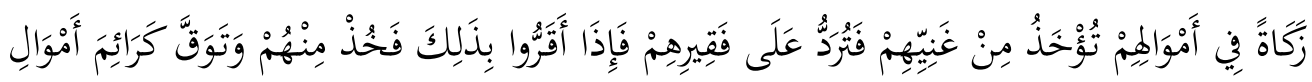

النَّاس

Telah menceritakan kepadaku Abdullah bin Abu Al Aswad telah menceritakan kepada kami AlFadll bin Al'Ala telah menceritakan kepada kami Ismail bin Umayyah dari Yabya bin Mubmmad bin Abdullab bin Shaifi ia mendengar Abu Ma'bad mantan budak Ibn Abbas, berkata, aku mendengar Ibn Abbas berkata, 'Dikala Nabi shallallahu 'alaibi wasallam mengutus $M u^{\prime}$ adz ke negeri Yaman, Nabi berpesan: "Wabai Mu'adz, engkau mendatangi kaum abli kitab, maka jadikanlah materi dakwah pertama-tama yang engkau sampaikan adalah agar mereka mentaubidkan Allah ta'ala. Jika mereka telah sadar terhadap hal ini, beritabulah mereka bahwa Allah mewajibkan lima shalat kepada mereka dalam sehari semalam. Jika mereka telah shalat, beritabulah mereka bahwa Allah mewajibkan zakat harta mereka, yang diambil dari yang kaya, dan diberikan kepada yang miskin, dan jika mereka telah mengikerarkan yang demikian, ambilah harta mereka dan jagalah harta mereka yang kesemuanya harus dijaga kehormatannya." 20

20 Kitab hadis shohih al- Bukhārī, jilid 1, Juz 1, hadis nomor 1365 sumber: http:/ $/$ www.infotbi.com/hadis9 $/$ cari hadist.php?imam $=$ bukhari\&keyNo $=1365 \& \mathrm{x}=0 \& \mathrm{xy}=0$ 
Dalam kitab hadis Ahmad umat Islam dianjurkan untuk berdiri memberi penghormatan dan menghormati jenazah orang Yahudi dengan teks hadis sebagai berikut:

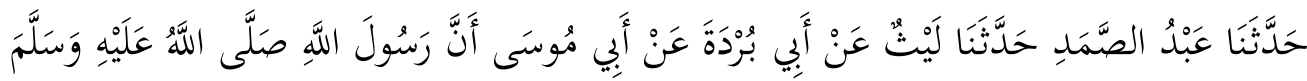

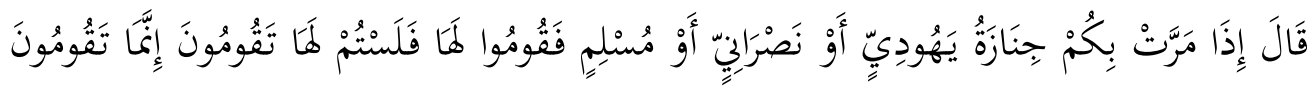
لِلمَنْ مَعَهَا مِنْ الْمَلَائِكَة

Telah menceritakan kepada kami Abdush Shamad Telah menceritakan kepada kami Laits dari Abu Burdah dari Abu Musa babwa Rasulullah shallallahu 'alaibi wasallam bersabda: "Apabila dibadapan kalian lewat jenazah orang yahudi atau nasrani atau muslim, maka bendaklah kalian berdiri! Berdiri tersebut bukan untuk menghormati jenazah itu, akan tetapi untuk. yang bersamanya yaitu para malaikat." 21

Sementara beberapa hadis yang dipandang diskriminatif mengenai hubungan Islam dan relasi agama-agama, diantaranya adalah: (1) hadis larangan memulainya memberi salam kepada kepada Non-Muslim, (2) hadis mengusir Non-Muslim dari tanah Arab.

Redaksi hadis larangan memulai memberi salam kepada kepada NonMuslim sebagaimana berikut:

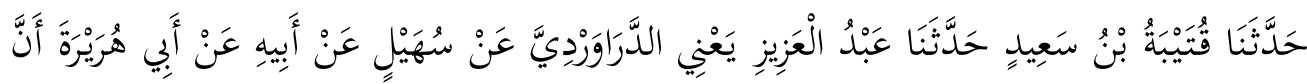

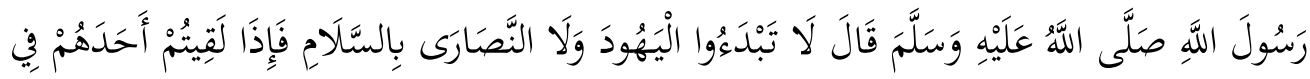

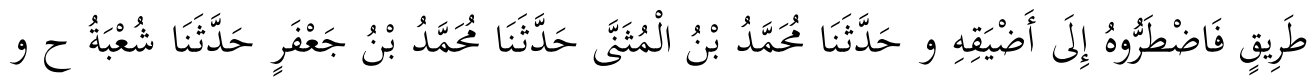

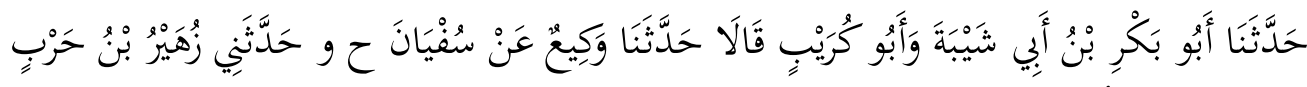

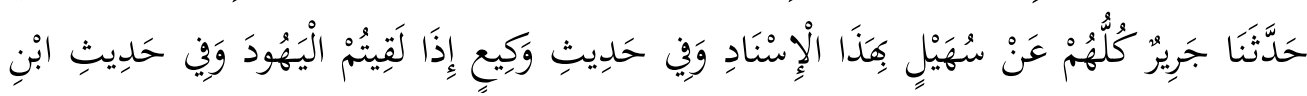

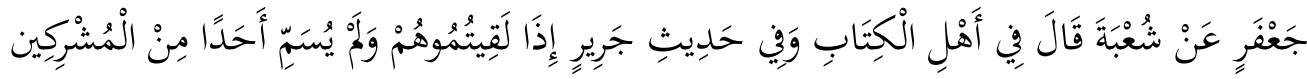

Telah menceritakan kepada kami Qutaibah bin Sa'id; Telah menceritakan kepada kami 'Abdul'Aziq yaitu Ad Daraawardi dari Subail dari Bapaknya dari Abu Hurairah babwa Rasulullah shallallabu 'alaibi wasallam bersabda: "Janganlah kalian mendahului orang-orang Yabudi dan Nasrani memberi salam. Apabila kalian berpapasan dengan salah seorang di

\footnotetext{
${ }^{21}$ Kitab Hadis Ahmad, Kitab: Musnad penduduk Kufah, Bab: Hadis Abu Musa Al Asy'ari Radliyallahu ta'ala 'anhu, No. Hadis: 18671 sumber: http:/ $/$ www.infotbi.com $/$ hadis $9 /$ cari hadist.php?imam $=$ ahmad\&keyNo $=18671 \& \mathrm{x}=0 \& \mathrm{y}=0$
} 
antara mereka di jalan, maka desaklah dia ke jalan yang paling sempit." Dan telah menceritakan kepada kami Muhammad bin AlMutsanna; Telah menceritakan kepada kami Muhammad bin Ja'far; Telah menceritakan kepada kami Syu'bah; Demikian juga diriwayatkan dari jalur yang lain; Dan telah menceritakan kepada kami Abu Bakr bin Abu Syaibah dan Abu Kuraib keduanya berkata; Telah menceritakan kepada kami Waki dari Sufyan; Demikian juga diriwayatkan dari jalur yang lain; Dan telab menceritakan kepadaku Zuhair bin Harb; Telah menceritakan kepada kami Jarir selurubnya dari Subail melalui sanad ini. Dan di dalam Hadits Waki' disebutkan; 'Apabila kalian bertemu dengan orang Yabudi.' Sedangkan dalam Hadits Ibnu Ja'far dari Syu'bah dia berkata mengenai ablu kitab juga di dalam Hadits Jarir dengan lafazb; "Apabila kalian bertemu dengan mereka.' (tanpa menyebutkan salah seorang di antara mereka).",22

Berikutnya hadis yang dipandang diskriminatif kaitannya Islam dan relasi agama-agama adalah mengusir Non-Muslim dari Jazirah Arab, sebagaimana berikut:

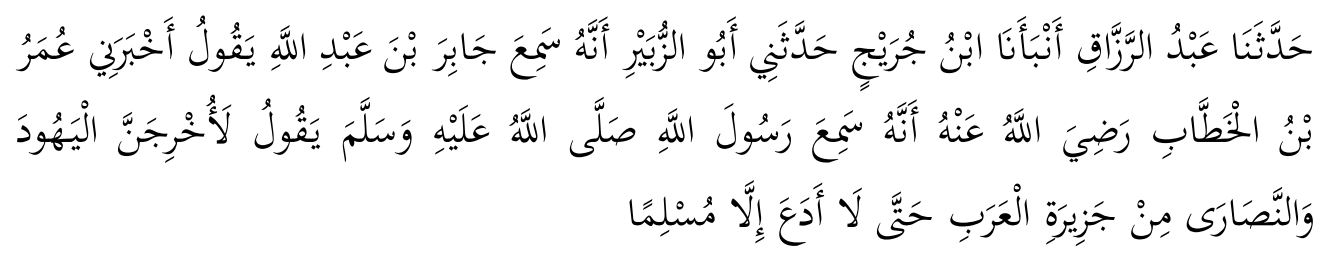

Telah menceritakan kepada kami Abdurrazaq telah memberitakan kepada kami Ibnu Juraij Telah menceritakan kepadaku Abu Az. Zubair babwa dia mendengar Jabir Bin Abdullah berkata; Telah menceritakan kepadaku Umar Bin Al Khaththab, bahwa dia telah mendengar Rasulullah shallallahu 'alaibi wasallam bersabda: "Sungguh aku akan mengeluarkan orang-orang Yahudi dan Nasrani dari Jazirah Arab, sebingga aku tidak tinggalkean di dalamnya kecuali orang muslim."23

Selanjutnya juga terdapat pada redaksi hadis sebagai berikut:

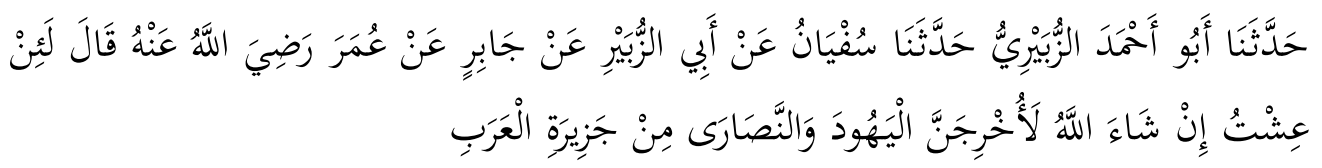

22 Kitab hadis Muslim, Kitab : Salam, Bab : Larangan memulai ahli kitab dalam memberikan salam, No. Hadist : 4030 sumber: http:/ / www.infotbi.com/hadis9/ cari hadist.php?imam $=$ muslim\&keyNo $=4030 \& x=0 \& y=0$

${ }^{23}$ Kitab hadis Ahmad, Kitab : Musnad sepuluh sahabat yang dijamin masuk surga, Bab : Awal musnad Umar bin Al Khatthab Radliyallahu 'anhu, No. Hadist : 196, sumber: http:/ www.infotbi.com/hadis9/cari hadist.php?imam $=$ ahmad\&keyNo $=196 \& x=0 \& y=0$ 
Telah menceritakan kepada kami Abu Abmad Az Zubairi Telah menceritakan kepada kami Sufyan dari Abu Az Zubair dari Jabir dari Umar dia berkata; "Tika aku bidup aku pasti akan mengeluarkan orang-orang yabudi dan Nasrani dari Jazirah Arab." 24

\section{Kajian tentang Kandungan Hadis Islam dan Relasi Agama- agama}

\section{Metode dan Interpretasi Para Ulama Hadis dalam Kitab-Kitab Syarah Hadis}

Salamah Noorhidayati mengungkapkan dengan penelitiannya tentang hadits tentang pergaulan dan relasi agama-agama bahwa hubungan antara Islam dan relasi agama-agama dibedakan menjadi tiga yaitu; akidah, ibadah, dan muamalah. Menurutnya pergaulan umat Islam dengan umat beragama lain tidak hanya bersinggungan pada persoalan muamalah, namun juga bersinggungan dalam hal akidah dan ibadah. Ketika kategori ini dilihat dari redaksional hadits ada yang yang bersifat akomodatif ada yang sifatnya diskriminatif. Tindakan diskriminatif tidak hanya dipandang sebagai sebuah tindakan yang bertentangan dengan prinsip universal tetapi juga bertentangan dengan konsep Islam rahmatan lil alamin ${ }^{25}$. Adanya praktik-praktik diskriminasi dalam kehidupan beragama tentu akan memberikan dampak negatif terhadap Islam dan relasi agama-agama. Namun demikian bila dilihat secara tekstual ada beberapa redaksional hadits yang menampakkan pandangan diskriminatif terhadap umat beragama. Pemaknaan hadis secara tekstual ini pernah dilakukan oleh orang-orang Islam dan bahkan ulama-ulama terdahulu sehingga perlunya memberikan pembacaan ulang terhadap hadits-hadits yang dipandang diskriminatif ini untuk mendapatkan dan mengetahui esensi dan substansi dari ajaran Islam.

Tesis Muhammad Syachrofi memaparkan tiga kategori contoh hadis yang dipandang diskriminatif. Pertama, larangan memulainya memberikan salam kepada (non-muslim). Kedua, adanya larangan melakukan persahabatan dengan non-muslim, dan ketiga mengusir non-muslim dari tanah Arab. Menurutnya hadis larangan memulai salam kepada non-muslim bila dilihat dari konteks sosio historisnya adalah kaum Yahudi yang sering memulai Mengucapkan salam dengan kalimat "al-sām alaikum" (celakalah atasmu!) yang ditujukan untuk memancing dan memperkeruh suasana. Hadits ini tidak ditujukan untuk seluruh umat non muslim di dunia tetapi hanya pada konteks saat itu aja. Seharusnya salam merupakan ucapan menyapa dalam bentuk kasih dan sayang dengan

\footnotetext{
${ }^{24}$ Kitab hadis Ahmad, Kitab : Musnad sepuluh sahabat yang dijamin masuk surga, Bab : Awal musnad Umar bin Al Khatthab Radliyallahu 'anhu, No. Hadist : 210 sumber: http: / $/$ www.infotbi.com $/$ hadis $9 /$ cari hadist.php? $\mathrm{imam}=\mathrm{ahmad} \& \mathrm{keyNo}=210 \& \mathrm{x}=0 \& \mathrm{ky}=0$

${ }^{25}$ Noorhidayati, "Hubungan Antar Umat Beragama Dalam Perpektif Hadits."
} 
mengucapkan salam. Seseorang yang mengucapkan salam kepada saudaranya meskipun belum dikenalnya akan memberi kesan lebih akrab, seseorang yang berada di sekitar akan menjadi lebih dekat dan memiliki kedekatan hubungan emosional ${ }^{26}$. Bila ucapan salam itu kemudian diganti dengan kalimat yang tidak semestinya tentu saja akan memberikan dampak negatif bagi orang yang menerima salam. Salam juga bisa dikatakan sebagai ungkapan universal dengan menggunakan bahasa apa pun dapat digunakan sebagai penyapa sehingga sampai kepada orang yang menerima salam. Ketika Gus Dur (KH. Abdurrahman Wahid) menjadi presiden pernah mengeluarkan isu akan mengganti kata assalamualaikum diganti dengan kata selamat pagi. Bila kita amati dan memandang dengan jernih, bukan berarti Gus Dur merubah tatanan keagamaan yang sudah terbangun sejak lama tetapi Gus Dur ingin memaknainya sebagai bagian membaca ulang dalam konteks sosial keagamaan, dalam hal ini adalah bagaimana umat beragama dengan umat beragama yang lain dapat mengucapkan salam secara universal.

Hadis yang berkaitan dengan hadis mengusir non muslim di Jazirah Arab sebagaimana Muhammad Syachrofi dalam tesisnya, bukan berarti umat Islam mengusir semua non muslim di seluruh dunia. Namun hal ini dikaitkan dengan orang non muslim yang mengingkari perjanjian Piagam Madinah bahkan mereka bersekongkol dengan kafir Quraisy untuk memerangi umat Islam. pada saat itu Nabi Muhammad berperan sebagai kepala pemerintahan di Madinah sehingga dikeluarkannya hadis ini dalam rangka menjaga stabilitas dan kondusifitas masyarakat Madinah ${ }^{27}$.

\section{Potret Islam dan Relasi Agama-agama dengan Sejarah Masa Nabi}

Madinah merupakan kota yang dipandang sebagai peradaban baru pada awal perkembangan Islam. Dalam pandangan fundamentalis jika dilihat dari bentuk masyarakatnya, mereka menyebut dengan istilah sebagai negara Madinah sementara pemikir liberal menyatakan menyebut masyarakat Madinah sebagai masyarakat madani ${ }^{28}$. Nabi Muhammad SAW meletakkan pondasi multikultural di Kota Madinah dalam segala lini kehidupan. Dudung Abdurahman menyebut kota Madinah sebagai kota multikultural dan bahkan Hal ini terlihat dari pemetaan atau sensus penduduk yang dilakukan oleh Nabi Muhammad terhadap penduduk Madinah. Hasil pemetaan sensus penduduk di Kota Madinah dari keseluruhan 10.000 penduduk, Ternyata jumlah kaum muslimin merupakan kaum minoritas yang hanya berjumlah 15\% (1.500 jiwa), sementara mayoritas penduduk tertinggi

${ }^{26}$ Muhammad Syachrofi, "Hadis-Hadis Diskriminasi Agama Dan Implikasi Terhadap Kerukunan Umat Beragama (Kajian Hermaneutika Hadis)" (Tesis: UIN Sunan Kalijaga Yogyakarta, 2019).

27 Syachrofi.

28 Muhammad Anang Firdaus, "Relasi Agama Dan Negara: Telaah Historis Dan Perkembangannya," Jurnal Multikultural \& Multireligius 13, no. 3 (2014): 165-74. 
adalah orang Arab yang masih musyrik sejumlah 45\% (4.500 jiwa), dan penduduk mayoritas kedua adalah penduduk Yahudi berjumlah $40 \%$ atau (4.000 jiwa) ${ }^{29}$.

Madinah merupakan kota yang subur yang ditempati oleh suku utama Khazraj dan Aus, disamping itu terdapat kalangan Yahudi dari Bani Quraizhah, bani Nadhir, dan bani Qunaiqo. ${ }^{30}$ Kehadiran Nabi Muhammad di kota Madinah pada tahun pertama yang dilakukan adalah dalam rangka mengurangi sekat antara kaum Muhajirin yang berlatar suku quraisy dan Anshor yang berlatar suku alKhazraj dan sebagian lainnya dari suku Al-Aus. Nabi Muhammad merubah paradigma masyarakat Ansor dan Muhajirin, yang awalnya ukhuwah persaudaraan merupakan persaudaraan berbasis darah dan nasab dirubah menjadi persaudaraan berbasis agama (ukhuwah Islamiyah). Konsep yang dilakukan oleh Nabi Muhammad ini berhasil merubah semangat sukuisme menjadi semangat persaudaraan ukhuwah islamiyah. Peran berikutnya yang dilakukan oleh Nabi Muhammad adalah membuat masjid yang digunakan sebagai pusat peribadatan, dakwah, dan dijadikan tempat untuk bermusyawarah ${ }^{31}$.

Dalam catatan sejarah ada dua umat beragama yang mendominasi relasi antara Islam dengan umat beragama tersebut, yaitu Yahudi dan Nasrani. Periode kepmimpinan Rasulullah ketika berada di Madinah tidak memaksakan kehendak beragama masuk Islam bagi kelompok Yahudi, Nasrani maupun kelompok kebatinan. Kelompok-kelompok ini mendapatkan perlakuan yang sama, melakukan kewajiban dan hak yang sama dengan pemeluk agama Islam ${ }^{32}$. Salamah Noorhidayati menjelaskan di dalam Alquran penyebutan istilah Yahudi dan Nasrani disebut dengan istilah ahli kitab. Islam dan Yahudi dalam relasi agama-agama memiliki kedekatan teologis hal ini bukan berarti Islam diturunkan (derivat) dari Yahudi melainkan adanya kesamaan dan kemiripan sumber yang menjadi basis teologi. Yahudi merupakan agama yang paling banyak bersentuhan dan bergesekan dengan Islam dan sampai pada perkembangan era kontemporer Timur Tengah, Yahudi menyisakan hubungan yang tidak pernah selesai dengan Islam, terutama dengan hadirnya Israel. Sementara Nasrani merupakan agama mayoritas kedua yang memiliki pola hubungan Islam dan relasi agama agama yang hidup di sekitaran Madinah. Nasrani karena ditopang oleh kekuasaan Romawi sehingga hampir di semua wilayah ada umat beragama Nasrani sehingga

29 Dudung Abdurahman, Komunitas Multikultural Dalam Sejarah Islam Periode Klasik (Yogyakarta: Penerbit Ombak; Yogyakarta, 2014).

${ }^{30}$ Khairunnas and Kasful Anwar, Pendidikan Islam (Perkembangan Sosial, Politik Dan Kebudayaan) (Jambi: Pustaka Ma’arif Press, 2018), https://doi.org/10.1088/1751 8113/44/8/085201.

${ }^{31}$ Noorhidayati, "Hubungan Antar Umat Beragama Dalam Perpektif Hadits."

32 Nurjanah Sumbulah, U., Pluralisme Agama Makna Dan Lokalitas Pola Kerukunan Antarumat Beragama (MAlang: UIN Maliki Press, 2013). 
pembacaan hadis haruslah secara menyeluruh dan komprehensif untuk mendapatkan substansi dari ajaran Islam ${ }^{33}$.

Peran berikut yang dilakukan oleh Nabi Muhammad adalah membuat perjanjian berupa piagam Madinah yang mengatur pola kehidupan masyarakat yang ada di sekitaran Madinah dan juga mengatur bagaimana pola relasi beragama bagi setiap penduduk kota Madinah. Manifestasi piagam Madinah ini memberikan dalam prakteknya memberikan kebebasan dalam memeluk agama bagi masyarakatnya hal ini dilakukan oleh Nabi Muhammad Khulafaur Rasyidin dan para khalifah setelah sehingga menjadikan masyarakat aman tentram dan damai dalam beragama ${ }^{34}$. Melelui konsep ummah yang kemudian lebih dikenal dengan Piagam Madinah Nabi Muhammad SAW menjaga memelihara, dan mengkonstruk kerukunan antar agama dan antar pemeluk agama ${ }^{35}$. Piagam Madinah ini salah satu fungsinya adalah dalam rangka mempersatukan kabilahkabilah dan suku-suku yang ada di Madinah untuk dapat berkomunikasi dengan baik dan saling hormat-menghormati dalam kehidupan sosial maupun keagamaan ${ }^{36}$. Dalam sejarah, disamping dua tersebut peran Nabi Muhammad saw memainkan peran dalam banyak fungsi, termasuk sebagai Nabi, sebagai pemimpin, kepala keluarga, kepala negara, pemimpin masyarakat, panglima perang, hakim, dan sebagai manusia biasa. Dengan demikian, hadits yang berasal dari Nabi mengandung petunjuk yang pemahaman dan penerapannya perlu dikaitkan dengan peran Nabi ketika hadits itu terjadi. ${ }^{37}$

Pola relasi Islam dengan agama-agama ini adalah menekankan dan menguatkan peran moderasi agama bagaimana memposisikan agama sebagai sesuatu yang berperan sebagai penengah dan ditempatkan sebagai penyelesaian masalah dan bukan sebagai sumber masalah. Noor Sulistyobudi, dkk menambahkan bahwa kebebasan beragama merupakan ciri dan corak khas dari masyarakat multikultural karenanya Nabi Muhammad dalam berdakwah menyebarkan Islam di kota Madinah menggunakan pendekatan dialogis sehingga masyarakat Islam di kota Madinah dapat hidup berdampingan dengan baik dengan Penduduk Madinah yang lainnya yang berlatar suku agama yang berbeda-beda. Implikasi dari dakwah dengan menggunakan pendekatan dialogis ini menjadikan dan mengurangi sikap-sikap yang radikal dan intoleran di tengah-tengah masyarakat yang plural. Artinya hikmah penting dari pendekatan dialog ini adalah

\footnotetext{
${ }^{33}$ Noorhidayati, "Hubungan Antar Umat Beragama Dalam Perpektif Hadits."

${ }^{34}$ Mu'allim, "Relasi Agama Dan Kekerasan."

${ }^{35}$ Maimun and Mohammad Kosim, Moderasi Islam Di Indonesia (Yogyakarta: LKiS, 2019).

${ }^{36}$ Noorhidayati, "Hubungan Antar Umat Beragama Dalam Perpektif Hadits."

${ }^{37}$ Muhammad Syuhudi Ismail, Hadis Nabi Yang Tekstual Dan Kontekstual: Telaah Ma'ani AlHadits Tentang Ajaran Islam Yang Universal, Temporal, Dan Lokal (Bulan Bintang, 1994), 4.
} 
bahwa masyarakat lebih menekankan dan menitikberatkan pada aspek aspek dialog dan bersikap toleran meskipun berbeda pendapat ${ }^{38}$.

\section{Relevansi Hadis Islam dan Relasi Agama-agama dengan Isu-Isu di Lembaga Pendidikan}

Dengan lebih dari 250 juta penduduk, terdiri dari lebih dari 13.000 pulau - besar dan kecil sehingga Indonesia dijadikan negara kepulauan terbesar di dunia. Indonesia adalah negara yang sangat beragam etnis, budaya, dan agama atau keyakinan. Muslim merupakan mayoritas di antara pemeluk agama lainnya termasuk Kristen, Hindu, Buddha dan Konghucu. Sejak lama, Indonesia digambarkan sebagai negara dengan catatan keragaman dan toleransi yang baik. Namun, ini tidak berarti meniadakan peristiwa-peristiwa yang merusak reputasi Indonesia. Konflik etnis dan agama telah memicu perselisihan antar kelompok dan sangat memerlukan perhatian perhatian ${ }^{39}$. Sementara Umi Kulsum menyebut tidak adanya toleransi dan rasa saling hormat menghormati di antara warga bangsa memberikan sumbangsih penyebab fenomena konflik dan perpecahan di Indonesia. Untuk itu, dengan adanya masyarakat yang bisa saling menghormati dan saling bertoleransi akan dapat memupuk rasa kesatuan bangsa Indonesia yang terdiri dari berbagai macam suku, adat, dan agama ${ }^{40}$.

Salah satu ajaran Islam adalah mengajarkan peran dan etika pergaulan umat Islam dengan agama-agama lainnya peran umat islam itu tidak hanya berada dalam lingkungan masyarakat atau pemerintahan tetapi juga pada di lembaga pendidikan ${ }^{41}$. Indonesia yang memiliki tipologi masyarakat majemuk dengan beragam kebiasaan adat suku dan agama memberikan bonus demografi namun disisi lain keberagaman penduduk ini ini memberikan potensi gesekan antar umat agama yang ada di masyarakat maupun d lingkungan pendidikan ${ }^{42}$. Bahkan dalam Al-Qur'an, Allah SWT juga menegaskan tentang pernyataan asal-usul manusia yang yang sangat multikultural. "Hai manusia, sesungguhnya kami menciptakan kamu dari seorang laki-laki dan seorang perempuan dan menjadikan kamu

\footnotetext{
${ }^{38}$ Sulistyobudi, Suta, and Salamun, Implementasi Pendidikan Multikultural Di SMA Daerah Istimewa Yogyakarta.

${ }^{39}$ Raihani, "A Model of Islamic Teacher Education for Social Justice in Indonesia a Critical Pedagogy Perspective," Journal of Indonesian Islam 14, no. 1 (2020): 163-86, https://doi.org/10.15642/JIIS.2020.14.1.163-186.

${ }^{40}$ Umi Kulsum, "Manajemen Pembelajaran Pendidikan Agama Islam (PAI) Dalam Mewujudkan Budaya Religius (Studi Di SMAN 1 Dan SMKN 1 Kota Metro)" (Disertasi: Universitas Islam Negeri Raden Intan Lampung, 2019), 82.

${ }^{41}$ Zaprulkhan, "Relasi Agama Dan Negara Dalam Perspektif Islam," Walisongo 22, no. 1 (2014): 105-32.

${ }^{42}$ Hamidah, "Strategi Membangun Kerukunan Umat Beragama," Wardab 17, no. 2 (2016): $123-36$.
} 
berbangsa-bangsa dan bersuku-suku supaya kamu saling kenal-mengenal. Sesungguhnya orang yang paling mulia di antara kamu di sisi Allah ialah orang yang paling taqwa di antara kamu. Sesungguhnya Allah Maha mengetahui lagi Maha Mengenal." (QS. al-Hujurat/49: 13).

Pendidikan multikultural merupakan pendidikan yang berkaitan dengan kebudayaan yang beragam sehingga kehadiran kurikulum yang dikembangkan harus dapat mengakomodir perbedaan kultural ${ }^{43}$. Salah satu masalah yang menjadi perhatian adalah ketidakadilan sosial dalam konteks pendidikan. Pengaturan sekolah yang berbeda dan menemukan bahwa tidak setiap siswa diperlakukan sama. Misalnya, pelajar agama bagi kaum minoritas mengalami diskriminasi dalam akses terhadap ajaran agama mereka dan perampasan terhadap praktik keagamaan mereka di sekolah. Minoritas yang dimaksud disini bukan berarti yang memiliki sedikit jumlah penduduk beragamanya, tetapi minoritas di tempat-tempat tertentu seperti muslim di Kalimantan Tengah atau bahkan dalam konteks skala mikro di lingkungan sekolah. Pada sekolah umum di Batam, kepala sekolah dengan persetujuan guru mengeluarkan kebijakan untuk membatasi jumlah siswa dari latar belakang etnis dan agama. Contoh lain dari ketidakadilan sosial ditemukan di sekolah dengan membedakan citra pada jurusan akademik. Jurusan IPA dianggap lebih bergengsi, dengan siswa yang digambarkan lebih rajin dan lebih pintar ${ }^{44}$. Bentuk-bentuk diskriminasi di level sekolah ini akan berdampak negatif bila dilakukan secara masif dan terus-menerus bagi warga sekolah, khususnya peserta didik. Untuk itu, penghapusan segala bentuk diskriminasi di lingkungan pendidikan adalah menjadi sebuah keharusan.

Sekolah merupakan lembaga pendidikan yang sangat tepat dijadikan sebagai wahana untuk membelajarkan multikultural kepada anak didik. Faktorfaktor yang memengaruhi bentuk pendidikan multikultural diantaranya bentuk kurikulum yang mendukung, usia guru, mata pelajaran yang diajarkan, hubungan guru dengan mata pelajaran, dan kurikulum ${ }^{45}$. Karakteristik multikultural dapat direfleksikan ke dalam elemen tujuan kurikulum, isi, situasi pembelajaran dan evaluasi. Desain kurikulum memiliki karakteristik multikultural jika tujuannya memiliki karakteristik peserta didik seperti memahami hak asasi manusia dan penghargaan terhadap pandangan yang berbeda, isinya terdiri dari beberapa mata pelajaran seperti hak asasi manusia dan kewarganegaraan, situasi pembelajaran

${ }^{43}$ Slamet, "Nilai-Nilai Multikulturalisme : Sebuah Implikasi \& Tantangan Negara-Bangsa Indonesia Ke Depan," Seminar Nasional Hasil Penelitian Dan Pengabdian Pada Masyarakat IV Tabun 2019 "Pengembangan Sumberdaya Menuju Masyarakat Madani Berkearifan Lokal" LPPM - Universitas Mubammadiyah Purwokerto ISBN: 978-602-6697-43-1, 2019, 224-31.

${ }^{44}$ Raihani, "A Model of Islamic Teacher Education for Social Justice in Indonesia a Critical Pedagogy Perspective."

45 Jana Kusá, Jana Sladová, and Kamil Kopecký, "Literary Education as a Place for Multicultural Dialogue," Procedia - Social and Behavioral Sciences 149 (September 5, 2014): 479-83, https://doi.org/10.1016/j.sbspro.2014.08.294. 
menawarkan kelompok yang berbeda ${ }^{46}$. Pelaksanaan pendidikan multikultural pada siswa yang homogen seperti di madrasah dan sekolah umum berbeda. Secara umum pendidikan multikultural sudah menjadi kebutuhan untuk diterapkan di lembaga pendidikan dengan peserta didik yang heterogen, terutama dari segi kepercayaannya. Nilai-nilai multikultural yang diajarkan di sekolah akan lebih mudah dipraktikkan dalam kehidupan sosial di antara siswa yang heterogen tersebut. Namun tidak demikian halnya dengan madrasah yang homogen pengembangan nilai multikultural di madrasah membutuhkan konsep dan strateginya sendiri.

Sebagaimana pelasanaan pendidikan multikultural yang dilakukan oleh Madrasah Pembangunan, Ciputat, Tangerang bukanlah hal baru karena nilai-nilai multikultural telah diajarkan dalam banyak mata pelajaran di sana. Nilai-nilai multikultural tersebut dikembangkan dan diperkenalkan serta dibutuhkan oleh siswa Madrasah Pembangunan untuk menghadapi masyarakat yang heterogen seperti nilai toleransi, empati, kerjasama; dan empat sifat utama Muhammad Rasululllah (sidiq, amanah, tabligh, fathonah). Nilai-nilai lainnya antara lain kepercayaan, kualitas kerja dan kompetitif ${ }^{47}$. Strategi pelaksanaannya dapat dilakukan melalui integrasi kurikulum pembelajaran ataupun bisa juga dilakukan dengan cara diintegrasikan dalam ekstrakurikuler. Praktek multikultural bisa dilakukan secara bersama-sama sebagai misal penelitian yang dilakukan oleh Sulistyowati, dkk yang mengambil latar SMA DIY Yogyakarta bahwa ketika melakukan doa bersama menjelang Ujian Nasional dikumpulkan dalam satu ruangan dan biasanya dibimbing oleh guru yang beragama Islam. Meskipun model dan tata cara permohonan doa disampaikan dengan cara menurut agama Islam, dalam memimpin doa guru beragama Islam tersebut menyampaikan kepada peserta doa untuk mengikuti bersama-sama doa yang sedang dipanjatkan berdasarkan agama dan kepercayaannya masing-masing. Bila masuk pada doa permohonan secara khusus, siswa-siswa dikelompokkan berdasarkan agamanya dengan cara memasuki ruangan masing-masing. Bagi siswa yang beragama Kristen dibimbing oleh guru Kristen, siswa beragama Katolik dipandu oleh guru beragama Katolik, dan begitu juga dengan siswa Hindu dibimbing oleh guru yang beragama Hindu ${ }^{48}$.

46 Nevcan Demir and Bünyamin Yurdakul, "The Examination of the Required Multicultural Education Characteristics in Curriculum Design," Procedia - Social and Behavioral Sciences 174 (February 12, 2015): 3651-55, https://doi.org/10.1016/j.sbspro.2015.01.1085.

${ }^{47}$ Muhamad Murtadlo, "Pendidikan Multikultural Di Madrasah Pembangunan Ciputat Tangerang," EDUKASI: Jurnal Penelitian Pendidikan Agama Dan Keagamaan 12, no. 2 (2014): 196209, https://doi.org/10.32729/edukasi.v12i2.82.

${ }^{48}$ Sulistyobudi, Suta, and Salamun, Implementasi Pendidikan Multikultural Di SMA Daerah Istimewa Yogyakarta. 
Berdasarkan pembahasan di atas, bila dikaitkan dengan hadis relasi antar umat beragama bahwa hehadiran sebuah hadits muncul sebagai respon terhadap suatu permasalahan dan kondisi masyarakat. relasi antara Muslim dan non-Muslim menunjukkan dinamika tertentu, terkadang dalam keadaan harmonis dan terkadang mengalami disharmonis. Kedua tersebut mencerminkan konteks kemunculannya secara historis dan sosial masyarakat. Patut diduga, kehadiran hadis-hadis yang apresiatif-akomodatif lahir dalam kondisi relasi sosial yang harmonis, sedangkan hadis-hadis yang kritis-konfrontatif lahir dalam kondisi relasi sosial yang tidak harmonis. Namun demikian, dalam memberi makna hadis perlu dilakukan pemaknaan ulang tidak hanya sekadar tekstual saja memandang non-Muslim sebagai manusia dengan segala hak yang melekat padanya melainkan juga dibaca secara kontekstual dengan latar yang mengitarinya. Dengan demikian, pemaknaan hadis yang harmonis dan disharmonis sesuai dengan maqam masingmasing sehingga tidak ada kesan bahwa Islam mengandung disharmoni dengan agama selain Islam melainkan dalam batas-batas yang memang harus berbeda dan tidak ada paksaan dalam agama (Islam).

\section{Kesimpulan}

Berdasarkan pembahasan masalah di atas, ada dua kesimpulan penting yang dapat dikemukakan pada tulisan ini. Pertama, secara tipologi hadis tentang Islam dan relasi agama-agama dapat dikategorikan dalam dua kategori bila dilihat dari redaksional hadis, sebagai berikut: (1) redaksional hadis yang menampakkan sikap akomodatif, dan (2) redaksional hadis yang menunjukkan sikap diskriminatif. Kehadiran suatu hadis ini dilatari oleh sebab musabab dan memberikan respon terhadap suatu masalah dan pada kondisi masyarakat tertentu.

Kehadiran hadits ini memberikan dua sikap sebagaimana telah dipaparkan dalam pembahasan, yaitu: ada hadits yang memberikan sikap akomodatif terhadap suatu permasalahan dan ada pula hadis yang memberikan sikap diskriminatif terhadap suatu persoalan. Artinya, hubungan Islam dan relasi agama-agama dalam hal ini hubungan antara Islam dengan Yahudi dan Nasrani menimbulkan kesan yang berfluktuasi dinamis, yaitu harmoni dan disharmoni, pasang dan surut, sehingga kadang-kadang menghasilkan hadis yang bersifat diskriminatif. Hal ini disebabkan karena orang Yahudi lebih dahulu memulai bersikap diskriminatif terhadap orang-orang Islam.

Pembacaan ulang hadis-hadis tentang Islam dan relasi agama-agama dalam konteks pendidikan dimaknai bahwa sekolah sebagai lembaga pendidikan merupakan wahana yang potensi dan kondusif untuk membelajarkan nilai-nilai multikultural. Meskipun peserta didik dalam suatu sekolah berlatar belakang yang berbeda-beda, baik itu berbeda latar etnis, budaya, suku, dan agama. Namun pada dasarnya dalam pelaksanaannya dapat dilakukan secara bersama-sama melalui integrasi kurikulum maupun integrasi dalam kegiatan ekstrakurikuler. 


\section{Bibliografi}

Abdurahman, Dudung. Komunitas Multikultural Dalam Sejarah Islam Periode Klasik. Yogyakarta: Penerbit Ombak; Yogyakarta, 2014.

Alwi, Zulfahmi, Rika Dwi Ayu Parmitasari, Alim Syariati, and Roziah binti Sidik. "Hadith Corresponding Thoughts on the Ethical Interacting Behavior of Young Entrepreneurs in Indonesia." Journal of Asian Finance, Economics and Business 8, no. 3 (2021): 331-39. https://doi.org/10.13106/jafeb.2021.vol8.no3.0331.

Chalis, M., and Syahril Syahril. "Education in the Perspective of Hadits (Analysis of Education in the Dimensions of the Hadith)." In Proceedings of the 1st International Conference on Social Science, Humanities, Education and Society Development, ICONS 2020, 30 November, Tegal, Indonesia. EAI, 2021. https://doi.org/10.4108/eai.30-11-2020.2303686.

Demir, Nevcan, and Bünyamin Yurdakul. "The Examination of the Required Multicultural Education Characteristics in Curriculum Design." Procedia - Social and Behavioral Sciences 174 (February 12, 2015): 3651-55. https://doi.org/10.1016/j.sbspro.2015.01.1085.

Faizal, P R M, A A M Ridhwan, and A W Kalsom. "The Entrepreneurs Characteristic from Al-Quran and Al-Hadis." International Journal of Trade, Economics and Finance 4, no. 4 (2013): 191-96.

Fauzi1, Ikmal Ahmad, and Ecep Ismail. "The Concept of Public Health from Hadith Perspective.” Gunung Djati Conference Series, Volume 4 (2021) Proceedings The 1st Conference on Ushuluddin Studies 4 (2021): 78-85.

Firdaus, Muhammad Anang. "Relasi Agama Dan Negara: Telaah Historis Dan Perkembangannya.” Jurnal Multikultural \& Multireligius 13, no. 3 (2014): 165-74.

Gümüsay, Ali Aslan. "Entrepreneurship from an Islamic Perspective." Springer Science+Business Media Dordrecht, no. September 2013 (2015): 199208. https://doi.org/10.1007/s10551-014-2223-7.

Hamidah. "Strategi Membangun Kerukunan Umat Beragama." Wardah 17, no. 2 (2016): 123-36.

Hoque, Nazamul, Abdullahil Mamun, and Abdullah Mohammad Ahshanul Mamun. "Dynamics and Traits of Entrepreneurship: An Islamic Approach." World Journal of Entrepreneurship, Management and Sustainable Development 10, no. 2 (2014): 128-42. https://doi.org/10.1108/wjemsd-04-2013-0027. 
Husain, Rahmin T., Arifuddin Ahmad, Siti Aisyah Kara, and Zulfahmi Alwi. "Polygamy in the Perspective of Hadith: Justice and Equality among Wives in A Polygamy Practice." MADANIA: JURNAL KAJIAN KEISLAMAN 23, no. 1 (July 7, 2019): 93. https://doi.org/10.29300/madania.v23i1.1954.

Ihya, M Saifuddin. “Water Management in Hadith Perspective.” Journal of Hadith Studies 1, no. 2 (October 25, 2018): 54-69. https://doi.org/10.32506/johs.v2i2.364.

Imroatun, Imroatun, and Difla Nadjih. "Anti-Violence Education in the Perspective of Hadith." Indonesian Journal of Islamic Early Childhood Education 1, no. 1 (2016): 121-30.

Ismail, Muhammad Syuhudi. Hadis Nabi Yang Tekstual Dan Kontekstual: Telaah Ma'ani Al-Hadits Tentang Ajaran Islam Yang Universal, Temporal, Dan Lokal. Bulan Bintang, 1994.

Istianah. "Kritik Terhadap Penisbatan Riwayat Hadis: Studi Atas Hadis-Hadis Palsu." Riwayah: Jurnal Studi Hadis 4, no. 1 (2018): 77-100. https://doi.org/http://dx.doi.org/10.21043/riwayah.v4i1.3319.

Kayed, Rasem N., and M. Kabir Hassan. "Islamic Entrepreneurship: A Case Study of Saudi Arabia." Journal of Developmental Entrepreneurship 15, no. 4 (2010): 379-413. https://doi.org/10.1142/S1084946710001634.

Khairunnas, and Kasful Anwar. Pendidikan Islam (Perkembangan Sosial, Politik Dan Kebudayaan). Jambi: Pustaka Ma'arif Press, 2018. https://doi.org/10.1088/1751-8113/44/8/085201.

Kulsum, Umi. "Manajemen Pembelajaran Pendidikan Agama Islam (PAI) Dalam Mewujudkan Budaya Religius (Studi Di SMAN 1 Dan SMKN 1 Kota Metro)." Disertasi: Universitas Islam Negeri Raden Intan Lampung, 2019.

Kusá, Jana, Jana Sladová, and Kamil Kopecký. "Literary Education as a Place for Multicultural Dialogue." Procedia - Social and Behavioral Sciences 149 (September 5, 2014): 479-83. https://doi.org/10.1016/j.sbspro.2014.08.294.

Maimun, and Mohammad Kosim. Moderasi Islam Di Indonesia. Yogyakarta: LKiS, 2019.

Maslani, Maslani, Ratu Suntiah, Yasniwarti Yasniwarti, and Ujang Dedih. "The Hadith Perspective on Educational Funding." In Proceedings of the International Conference on Islamic Education (ICIE 2018), 261:288-92. Paris, France: Atlantis Press, 2018. https://doi.org/10.2991/icie18.2018.52. 
Mohseni, Tahere, and Khadijeh Ahmadi Bighash. "Psychological Effects of Charitable Activities on the Worldly Mental Health and Eternal Happiness of the Hereafter from the Perspective of the Qur'an and Hadith." International Journal of Multicultural and Multireligious $\begin{array}{llllll}\text { Understanding } & 7, & \text { no. } & 6 & \text { (2020): } & 180 .\end{array}$ https://doi.org/10.18415/ijmmu.v7i6.1625.

Mostafazadeh, A, and HR Khorasani. "Holy Quran and Hadith Perspective on Fasting and Immune System." Islam And Health Journal, 2014, 61-68. http://www.iahj.ir/browse.php?a_id=69\&slc_lang=en\&sid=1\&printcas $\mathrm{e}=1 \& \mathrm{hbnr}=1 \& \mathrm{hmb}=1$.

Mu'allim, Amir. "Relasi Agama Dan Kekerasan.” Unisia 29, no. 61 (September 21, 2006): 257-65. https://doi.org/10.20885/unisia.vol29.iss61.art2.

Murtadlo, Muhamad. "Pendidikan Multikultural Di Madrasah Pembangunan Ciputat Tangerang." EDUKASI: Jurnal Penelitian Pendidikan Agama Dan Keagamaan 12, no. 2 (2014): 196-209. https://doi.org/10.32729/edukasi.v12i2.82.

Nasrullah. "Metodologi Kritik Hadis: (Studi Takhrij Al-Hadis Dan Kritik Sanad)." Jurnal Hunafa 4, no. 4 (2007): 403-16.

Noorhidayati, Salamah. "Hubungan Antar Umat Beragama Dalam Perpektif Hadits." KALAM 10, no. 2 (December 30, 2016): 491-516.

Rahman, Sira. "Religion and Animal Welfare-An Islamic Perspective." Animals 7, no. 12 (February 17, 2017): 11. https://doi.org/10.3390/ani7020011.

Raihani. "A Model of Islamic Teacher Education for Social Justice in Indonesia a Critical Pedagogy Perspective." Journal of Indonesian Islam 14, no. 1 (2020): 163-86. https://doi.org/10.15642/JIIS.2020.14.1.163-186.

Sismanto, and Riswadi. "Forms of Cooperation Between Religions; A Tafsir Perspektif." Syamil: Journal of Islamic Education 9, no. 1 (2021): 21-38. https://doi.org/10.21093/sy.v9i1.3201.

Slamet. "Nilai-Nilai Multikulturalisme: Sebuah Implikasi \& Tantangan NegaraBangsa Indonesia Ke Depan." Seminar Nasional Hasil Penelitian Dan Pengabdian Pada Masyarakat IV Tahun 2019 "Pengembangan Sumberdaya Menuju Masyarakat Madani Berkearifan Lokal" LPPM Universitas Muhammadiyah Purwokerto ISBN: 978-602-6697-43-1, 2019, 224-31.

Sulistyobudi, Noor, Bambang Suta, and Salamun. Implementasi Pendidikan Multikultural Di SMA Daerah Istimewa Yogyakarta. Yogyakarta: Balai Pelestarian Nilai Budaya (BPNB) Yogyakarta, 2014. 
Sumbulah, U., Nurjanah. Pluralisme Agama Makna Dan Lokalitas Pola Kerukunan Antarumat Beragama. MAlang: UIN Maliki Press, 2013.

Sumbulah, Umi, and Wilda Al Aluf. Fluktuasi Relasi Islam-Kristen Di Indonesia Pendekatan Sosio-Historis. Malang: UIN Maliki Press, 2015.

Suparman, Heru. "Multikultural Dalam Perspektif Alquran.” AL QUDS : Jurnal Studi Alquran Dan Hadis 1, no. 2 (December 1, 2017): 2580-3190. https://doi.org/10.29240/alquds.v1i2.250.

Syachrofi, Muhammad. "Hadis-Hadis Diskriminasi Agama Dan Implikasi Terhadap Kerukunan Umat Beragama (Kajian Hermaneutika Hadis)." Tesis: UIN Sunan Kalijaga Yogyakarta, 2019.

Zaprulkhan. "Relasi Agama Dan Negara Dalam Perspektif Islam.” Walisongo 22, no. 1 (2014): 105-32. 